\title{
Antimicrobial Susceptibility Patterns of the Bacterial Isolates in Post-Operative Wound Infections in a Tertiary Care Hospital, Kathmandu, Nepal
}

\author{
Mohammad Shahid Raza ${ }^{1}$, Anil Chander ${ }^{1 *}$, Abirodh Ranabhat ${ }^{2}$ \\ ${ }^{1}$ Department of Microbiology, Kathmandu Medical College Teaching Hospital, Sinamangal, Kathmandu, Nepal \\ ${ }^{2}$ Department of Surgery, Kathmandu Medical College Teaching Hospital, Sinamangal, Kathmandu, Nepal \\ Email: *drchandera@gmail.com
}

Received June 29, 2013; revised July 29, 2013; accepted August 5, 2013

Copyright (C) 2013 Mohammad Shahid Raza et al. This is an open access article distributed under the Creative Commons Attribution License, which permits unrestricted use, distribution, and reproduction in any medium, provided the original work is properly cited.

\begin{abstract}
Unrestrained anti-microbial resistance (AMR) among bacterial pathogens has made the management and treatment of post-operative wound infections difficult. This study assessed the current AMR patterns of bacterial isolates in post-operative wound infections in a tertiary care hospital in Kathmandu, Nepal. Pus swabs collected from postoperative wound infections and submitted for culture and sensitivity were included in this study. Isolation and identification of the organism was done by standard microbiological methods. Antibiotic susceptibility test was performed by Kirby Bauer disc diffusion method and result was interpreted as per National Committee for Clinical Laboratory Standards (NCCLS) guide lines. Of the 120 pus swabs processed for culture, 96 showed bacterial growth. Staphylococcus aureus $36(37.5 \%)$ was the predominant gram positive isolate and Escherichia coli $24(25 \%)$ was the major gram negative isolate. The infection was most prevalent in the age group $21-40$ years. All S. aureus isolates were sensitive to aminoglycosides and vancomycin. Out of $36 \mathrm{~S}$. aureus, $15(41.66 \%)$ isolates were methicillin resistant S. aureus (MRSA). Staphylococcus epidermidis showed high resistance $(50 \%-100 \%)$ to all antibiotics but were sensitive to vancomycin. All gram negative isolates showed high resistance against cephalexin $(75 \%-100 \%)$ and ceftriaxone $(25 \%-100 \%)$. Overall multi-drug resistant isolates were $66.7 \%$. A high level of AMR was observed in gram negative bacterial isolates. Rational use of antibiotics and a regular monitoring of AMR patterns in post-operative wound infections are essential and mandatory to avert further emergence and spread of anti-microbial resistance among bacterial pathogens.
\end{abstract}

Keywords: Antimicrobial Resistance; Bacterial Isolates; Nepal; Post-Operative Wound Infections

\section{Introduction}

Unrestrained and rapidly spreading anti-microbial resistance among bacterial populations has made the management and treatment of post-operative wound infections a serious challenge in clinical and surgical practice. Patients with post-operative wound infections face additional exposure to microbial populations circulating in a hospital set up as the hospital environment is always charged with microbial pathogens. Most post-operative wound infections are hospital acquired, and vary from one hospital to the other and are associated with complications, increased morbidity and mortality $[1,2]$. The emergence of bacterial AMR has made the choice of empirical therapy more difficult and expensive [3]. Wound

${ }^{*}$ Corresponding author. infections by resistant bacteria have further deteriorated the condition in this regard [4]. Rapid spread of resistant microbes affected the effectiveness of antimicrobials and created world-wide problem [5]. The condition is serious in developing countries owing to irrational prescriptions of antimicrobial agents [6]. These surgical site infections (SSIs) rates varied from $2.5 \%$ to $41.9 \%$ [7]. Several reports have illustrated the etiologic agents involved in SSIs and their AMR patterns in India [7,8], Pakistan [9], Italy [10], Nigeria [3,11] and Uganda [12]. Reports investigating antimicrobial resistance among bacterial pathogens involved in post-operative wound infections are limited in Nepal $[13,14]$.

As the AMR patterns of the bacterial isolates keep changing and evolving with time and place, this study was conducted to assess the current status of bacterial 
pathogens involved in post-operative wound infections and their AMR patterns in a centrally located tertiary care hospital in Kathmandu, Nepal.

\section{Materials and Methods}

\subsection{Setting}

This prospective study was conducted at the Department of Microbiology Kathmandu Medical College Teaching Hospital in Kathmandu, Nepal. Patients were enrolled after obtaining informed consent from them or their attendants.

\subsection{Specimens}

The pus swabs were obtained from patients admitted in the post-operative ward of the hospital, after undergoing surgery from January 2012 to September 2012. The pus swab samples were obtained before cleaning of the wounds and were processed for isolation and identification of bacterial pathogens according to the standard microbiological techniques. Two pus swabs were collected aseptically with a sterile cotton swab from each patient $(n=120)$ clinically suspected of infected wounds.

\subsection{Identification of Bacterial Isolates}

Gram stained preparations were made from one swab collected and the other swabs were used for the isolation of the organism and inoculated on blood agar, MacConkey agar and mannitol salt agar. Culture plates were incubated aerobically at $37^{\circ} \mathrm{C}$ for 24 to 48 hours. Growth on culture plates were identified by colony characteristics and further identified by gram staining and standard biochemical tests [15].

\subsection{Antimicrobial Susceptibility Testing}

The antimicrobial susceptibility testing was done on Mueller Hinton agar by the Kirby Bauer disc diffusion method [16] and results were interpreted as per NCCLS guide line [17]. S. aureus (ATCC 25923), E. coli (ATCC 25922) and $P$. aeruginosa (ATCC 27853) were used for the quality control, monitoring the performance and to ensure accuracy and reproducibility of all the tests carried out. Antibiotics used were: amikacin $(30 \mu \mathrm{g})$, gentamicin $(10 \mu \mathrm{g})$, cotrimoxazole $(23.75 / 1.25 \mu \mathrm{g})$, piperacillin $(100 \mu \mathrm{g})$, vancomycin $(30 \mu \mathrm{g})$, norfloxacin $(10$ $\mu \mathrm{g})$, ofloxacin $(5 \mu \mathrm{g})$, Ceftriaxone $(30 \mu \mathrm{g})$, cephalexin $(30 \mu \mathrm{g})$, ciprofloxacin $(30 \mu \mathrm{g})$ and oxacillin $(1 \mu \mathrm{g})$. $S$. aureus isolates resistant to oxacillin $(1 \mu \mathrm{g})$ were identified as MRSA and those susceptible as methicillin sensitive S. aureus (MSSA). Data analysis was carried out using SPSS10.

\section{Results}

Pus swabs from 120 post-operative wound infections were analyzed in this study and processed for culture. Bacterial isolates were obtained from 96 pus swabs. The predominant isolates were gram positive bacteria 40 (41.67\%). The most frequently isolated organisms were $S$. aureus $36(37.5 \%)$ followed by E. coli 24 (25\%), Klebsiella pneumoniae 10 (10.4\%) and Citrobacter spp. 9 (9.38\%) (Table 1). Among gram positive bacterial isolates $S$. aureus showed high level of drug resistance to piperacillin $15(41.66 \%)$, oxacillin $15(41.66 \%)$ and cotrimoxazole 12 (33.33\%). Staphylococcus epidermidis showed a very high drug resistance level $75 \%-100 \%$ to cotrimoxazole, amikacin, gentamicin, ciprofloxacin and oxacillin (Table 2). Of the gram negative isolates Klebsiella pneumoniae, Acinetobacter spp. and E. coli showed resistance to most of the antibiotics. All Acinetobacter spp. were found to be resistance to cephalexin and Proteus vulgaris were resistance to ceftriaxone, cephalexin and ciprofloxacin. Drug resistance pattern of gram negative isolates are summarized in (Table 3). Bacterial isolates that showed in-vitro resistance to more than one antimicrobial agent (or resistance to two or more classes of antibiotics) were considered to be multi drug resistance [18]. Overall, $64(66.67 \%)$ of the bacterial isolates showed multi drug resistance in this study, while $26(27.08 \%)$ of the isolates were resistance to one antibiotic and only $6(6.25 \%)$ isolates were found to be sensitive to all the antibiotics tested as depicted in (Table 4).

Table 1. Prevalence of bacterial isolates in post-operative wound infections.

\begin{tabular}{ccc}
\hline Bacteria & No. of isolates & $\begin{array}{c}\text { Percentage } \\
(\%) \text { of isolates }\end{array}$ \\
\hline Staphylococcus aureus & 36 & 37.50 \\
Escherichia coli & 24 & 25.00 \\
Klebsiella pneumoniae & 10 & 10.41 \\
Citrobacter species. & 9 & 9.38 \\
Pseudomonas aeruginosa & 6 & 6.25 \\
Staphylococcus epidermidis & 4 & 4.17 \\
Acinetobacter species. & 4 & 4.17 \\
Proteus vulgaris & 3 & 3.13 \\
Total & 96 & 100.00 \\
\hline
\end{tabular}

Table 2. Antibiotic resistance patterns of Gram positive organisms.

\begin{tabular}{ccc}
\hline \multirow{2}{*}{ Antibiotic } & $\begin{array}{c}\text { Staphylococcus } \\
\text { aureus } \mathbf{n}=\mathbf{3 6}\end{array}$ & $\begin{array}{c}\text { Staphylococcus epidermidis } \\
\mathbf{n}=\mathbf{4}\end{array}$ \\
\cline { 2 - 3 } & Resistance (\%) & Resistance (\%) \\
\hline Amikacin & 0 & $3(75)$ \\
Gentamicin & 0 & $3(75)$ \\
Ciprofloxacin & $9(25)$ & $3(75)$ \\
Cotrimoxazole & $12(33.33)$ & $4(100)$ \\
Piperacillin & $15(41.66)$ & $2(50)$ \\
Oxacillin & $15(41.66)$ & $3(75)$ \\
Vancomycin & 0 & 0 \\
\hline
\end{tabular}


Table 3. Antibiotic resistance patterns of Gram negative organisms.

\begin{tabular}{|c|c|c|c|c|c|c|}
\hline \multirow[t]{2}{*}{ Antibiotic } & $\begin{array}{c}\text { Escherichia } \\
\text { coli } \\
\mathrm{n}=24(\%)\end{array}$ & $\begin{array}{c}\text { Klebsiella } \\
\text { pneumoniae } \\
\mathrm{n}=10(\%)\end{array}$ & $\begin{array}{c}\text { Citrobacter } \\
\text { spp. } \\
\mathbf{n}=\mathbf{9}(\%)\end{array}$ & $\begin{array}{c}\text { Pseudomonas } \\
\text { aeruginosa } \\
\text { n = } 6(\%)\end{array}$ & $\begin{array}{c}\text { Acinetobacter } \\
\text { spp. } \\
\mathrm{n}=\mathbf{4}(\%)\end{array}$ & $\begin{array}{c}\text { Proteus } \\
\text { vulgaris } \\
\mathrm{n}=3\end{array}$ \\
\hline & \multicolumn{6}{|c|}{ Resistance (\%) } \\
\hline Amikacin & $6(25)$ & $5(50)$ & 0 & 0 & $2(50)$ & 0 \\
\hline Gentamicin & $6(25)$ & $3(30)$ & 0 & 0 & $3(75)$ & 0 \\
\hline Norfloxacin & $6(25)$ & $3(30)$ & $6(66.7)$ & 0 & $1(25)$ & 0 \\
\hline Ofloxacin & $9(37.5)$ & $3(30)$ & $6(66.7)$ & 0 & $2(50)$ & 0 \\
\hline Ceftriaxone & $6(25)$ & $7(70)$ & $6(66.7)$ & $3(50)$ & $2(50)$ & $3(100)$ \\
\hline Cephalexin & $18(75)$ & $8(80)$ & $9(100)$ & $6(100)$ & $4(100)$ & $3(100)$ \\
\hline Ciprofloxacin & $6(25)$ & $3(30)$ & $3(33.3)$ & $3(50)$ & $3(75)$ & $3(100)$ \\
\hline Cotrimoxazole & $15(37.5)$ & $8(80)$ & $3(33.3)$ & $6(100)$ & $2(50)$ & $3(100)$ \\
\hline
\end{tabular}

Table 4. Distribution of multi-drug resistant bacterial isolates.

\begin{tabular}{cccc}
\hline Organisms & $\mathbf{S}, \mathbf{n}(\mathbf{\%})$ & $\mathbf{R}_{\mathbf{1}}, \mathbf{n}(\mathbf{\%})$ & $\mathbf{R}_{\mathbf{M}}, \mathbf{n}(\mathbf{\%})$ \\
\hline S. aureus & $3(8.3)$ & $18(50)$ & $15(41.7)$ \\
E. coli & $3(12.5)$ & $3(12.5)$ & $18(75)$ \\
Klebsiella pneumonia & 0 & $2(20)$ & $8(80)$ \\
Citrobacter species & 0 & $3(33.3)$ & $6(66.7)$ \\
Pseudomonas aeruginosa & 0 & 0 & $6(100)$ \\
Staphylococcus epidermidis & 0 & 0 & $4(100)$ \\
Acinetobacter spp & 0 & 0 & $4(100)$ \\
Proteus vulgaris & 0 & $26(27.08)$ & $3(100)$ \\
Total & $6(6.25)$ & $04(66.67)$
\end{tabular}

Note: $\mathrm{n}=$ Number of bacterial isolates, $\mathrm{S}=$ Sensitive to all antibiotics tested, $\mathrm{R}_{1}=$ Resistance to one class of antibiotics, $\mathrm{R}_{M}=\mathrm{Resistance}$ to 2 or more classes of antibiotics (multi-drug resistant).

\section{Discussion}

Management and treatment of post-operative wound infections remain a significant concern for surgeons and physicians in a health care facility. The problem has been magnified due to the unrestrained and rapidly spreading resistance to the available array of antimicrobial agents, the only choice with us to treat the infections. In-patients face additional exposure to hospital acquired infections due to longer stays. Data on the AMR in bacterial populations are very limited in Nepal especially involving post-operative wound infections. The selection of patients was restricted to those admitted in the post-operative surgical wards after undergoing various surgeries as the infection rates are highest in the surgical wards among the clinical departments. 56 (58.33\%) were Gram negative isolates involved in causing post-operative wound infections. Similar observations have been reported from Nigeria $[19,20]$. This could be attributed to be acquired from patient's normal endogenous microbial fecal flora [7,21]. The presence of enteric organisms probably resulted in subsequent sepsis [1,22]. E. coli 24 $(42.9 \%)$ was the commonest gram negative bacteria iso- lated. E. coli invasion of the wound is a clear case of poor hospital hygiene, just like other implicated organisms which are frequent agents of nosocomial infections [23]. S. aureus $36(37.5 \%)$ was the single predominant gram positive bacterial isolate obtained. Several reports have cited $S$. aureus as the predominant isolate involved in causing SSIs $[1,3,5,7]$.

Susceptibility outcome revealed that vancomycin was the most effective antibiotic against the gram positive bacteria. Aminoglycosides were effective against both gram positive and gram negative bacteria. A study conducted in Kenya [3] had reported that gentamicin were effective against most of the isolates of E. coli, Pseudomonas aeruginosa and Proteus vulgaris. AMR was higher among gram negative isolates as compared to the gram positive bacteria. Similar results were reported earlier [11]. 64/96 (66.7\%) of all bacterial isolates screened showed multi drug resistance (MDR), where as MDR rate was very high, $80.36 \%$ (45/54) among gram negative bacterial isolates tested.

MDR among gram positive isolates was found to be $19 / 40=47.5 \%$. A study conducted in Nepal [14] in 2003 reported that $47.2 \%$ of the bacterial isolates were mul- 
tidrug resistant. This situation raises a serious concern. This suggests a very high resistance gene pool due perhaps to gross misuse, overuse and inappropriate use of the antibacterial agents [11]. The pattern is best understood in terms of selective pressure exerted on the organisms based on the current antibiotics use. Fluoro-quinolones and aminoglycosides are being more frequently prescribed in our settings. Hospitals provide an environment conducive to the spread of resistant organisms among population [24]. Additionally, higher multidrug resistance frequencies in a hospitalized population with intense exposure to antibiotics had been reported [25]. Limitations of the study being that anaerobic bacteria profile and fungal cultures were not done on wound swabs obtained from post-operative wound infection. A continuous monitoring and update studies on the local microbial isolates are an essential and mandatory requirement for a better management and treatment of post-operative wound infections. This would be supplemented with proper infection prevention and control measures and a sound antibiotic policy. This would result in better patient care, safety and health care outcomes.

\section{Acknowledgements}

The authors are thankful to the technical staff in the hospital laboratory for helping in performing the investigations.

\section{REFERENCES}

[1] J. O. Isibor, A. Oseni, A. Eyaufe, R. Osagie and A. Turay, "Incidence of Aerobic Bacteria and Candida albicans in Post-Operative Wound Infections," African Journal of Microbiology Research, Vol. 2, No. 11, 2008, pp. 288291.

[2] K. B. Kirkland, J. P. Briggs, S. L. Trivetta and W. E. Wilkinson, "The Impact of Surgical Site Infections in the 1990s: Attributable Mortality, Excess Length of Hospitalization, and Extra Costs," Infection Control and Hospital Epidemiology, Vol. 20, No. 11, 1999, pp. 725-730. doi:10.1086/501572

[3] J. Andhoga, A. G. Macharia, I. R. Maikuma, Z. S. Wanyonyi, B. R. Ayumba and R. Kakai, "Aerobic Pathogenic Bacteria in Post-Operative Wounds at Moi Teaching and Referral Hospital," East African Medical Journal, Vol. 79, No. 12, 2002, pp. 640-644. doi:10.4314/eamj.v79i12.8671

[4] A. F. Moges, A. Genetu and G. Mengistu, "Antibiotics Sensitivity of Common Bacterial Pathogens in Urinary Tract Infections at Gondar Hospital, Ethiopia," East African Medical Journal, Vol. 79, No. 3, 2002, pp. 140-142. doi:10.4314/eamj.v79i3.8893

[5] F. Biadglegne, B. Abera, A. Alem and B. Anagaw, "Bacterial Isolates from Wound Infections and Their Antimicrobial Susceptibility Patterns in Felege Hiwot Referral Hospital, North West Ethiopia," Ethiopian Journal of Health Sciences, Vol. 19, No.3, 2009, pp. 173-177.
[6] B. Roma, S. Worku, S. T. Marium and N. Langeland, "Antimicrobial Susceptibility Pattern of Shigella Isolates in Awassa," Ethiopian Journal of Health Development, Vol. 14, No. 2, 2000, pp. 149-154. doi:10.4314/ejhd.v14i2.9914

[7] S. Malik, A. Gupta, K. P. Singh, J. Agarwal and M. Singh, "Antibiogram of Aerobic Bacterial Isolates from PostOperative Wound Infections at a Tertiary Care Hospital in India," Journal of Infectious Diseases Antimicrobial Agents, Vol. 28, No. 1, 2011, pp. 45-51.

[8] M. Arya, P. K. Arya, D. Biswas, R. Prasad, "Antimicrobial Susceptibility Pattern of Bacterial Isolates from Post-Operative Wound Infections," Indian Journal of Pathology and Microbiology, Vol. 48, No. 2, 2005, pp. 266269.

[9] S. A. Ali, S. M. Tahir, A. S. Memon and N. A. Shaikh, "Pattern of Pathogens and Their Sensitivity Isolated from Superficial Surgical Site Infections in a Tertiary Care Hospital," Journal of Ayub Medical College Abbottabad, Vol. 21, No. 2, 2009, pp. 80-82.

[10] A. Giacometti, O. Cirioni, A. M. Schimizzi, M. S. Del Prete, F. Barchiesi, M. M. D'Errico, E. Petrelli and G. Scalise, "Epidemiology and Microbiology of Surgical Wound Infections," Journal of Clinical Microbiology, Vol. 38, No. 2, 2000, pp. 918-922.

[11] A. A. Adegoke, T. Mvuyo, A. I. Okoh and J. Steve, "Studies on Multiple Antibiotic Resistant Bacteria Isolated from Surgical Site Infection," Scientific Research and Essays, Vol. 5, No. 24, 2010, pp. 3876-3881.

[12] J. R. Anguzu and D. Olila, "Drug Sensitivity Patterns of Bacterial Isolates from Septic Post-Operative Wounds in a Regional Referral Hospital in Uganda," African Health Sciences, Vol. 7, No. 3, 2007, pp. 148-154.

[13] B. R. Giri, H. P. Pant, P. R. Shankar, C. T. Sreeramareddy, P. K. Sen, "Surgical Site Infection and Antibiotics Use in a Tertiary Care Hospital in Nepal,' Journal of Pakistan Medical Association, Vol. 58, No. 3, 2008, pp. 148-151.

[14] M. R. Banjara, A. P. Sharma, A. B. Joshi, N. R. Tuladhar, P. Ghimire and D. R. Bhatta, "Surgical Wound Infections in Patients of Tribhuvan University Teaching Hospital, Journal of Nepal Health Research Council, Vol. 1, No. 2, 2003, pp. 41-45.

[15] M. Cheesbrough, "District Laboratory Practice in Tropical Countries Part 2," Cambridge University Press, Cambridge, 2000.

[16] A. W. Bauer, M. Kirby, J. D. Sheris and M. Turch, "Antibiotic Susceptibility Testing by Standard Single Disc Method," American Journal of Clinical Pathology, Vol. 45, No. 4, 1966, pp. 493-496.

[17] National Committee for Clinical Laboratory Standards, "Performance Standards for Antimicrobial Disc Susceptibility Testing," 2004.

[18] A. P. Magiorakos, A. Srinivasan, R. B. Carey, Y. Carmeli, M. E. Falagas, C. G. Giske, et al., "Multidrug-Resistant, Extensively Drug-Resistant and Pandrug-Resistant Bacteria: An International Expert Proposal for Interim Standard Definitions for Acquired Resistance," Clinical Microbiology Infection, Vol. 18, No. 3, 2012, pp. 268-281. doi:10.1111/j.1469-0691.2011.03570.x 
[19] S. S. Taiwo, A. B. Okesina and B. A. Onile, "Invitro Antimicrobial Susceptibility Pattern of Bacterial Isolates from Wound Infections in University of Ilorin Teaching Hospital," African Journal of Clinical and Experimental Microbiology, Vol. 3, No. 1, 2002, pp. 6-10. doi:10.4314/ajcem.v3i1.7342

[20] F. T. Ogunsola, O. Odeyebo, K. C. Iregbu, A. O. Coker and A. Adetunji, "A Review of Nosocomial Infection at the Lagos University Teaching Hospital: Problems and Strategies for Improvement," Journal of Nigerian Infection Control Association, Vol. 1, No. 1, 1998, pp. 1113.

[21] R. L. Nichols, "Surgical Wound Infection," American Journal of Medicine, Vol. 91, No. 3, 1991, pp. S54-S64. doi:10.1016/0002-9343(91)90344-W

[22] S. L. Gorbach and J. G. Bartlett, "Anaerobic Infections," New England Journal of Medicine, Vol. 290, No. 21, 1974, pp. 1177-1184. doi:10.1056/NEJM197405232902106

[23] S. O. Samuel, O. O. Kayode, O. I. Musa, G. C. Nwigwe, A. O. Aboderin, T. A. T. Salami and S. S. Taiwo, "Nosocomial Infections and the Challenges of Control in Developing Countries," African Journal of Clinical and Experimental Microbiology, Vol. 11, No. 2, 2010, pp. 102110. doi:10.4314/ajcem.v11i2.53916

[24] J. L. Walson, B. Marshall, B. M. Pokhrel, K. K. Kafle and S. B. Levy, "Carriage of Antibiotic-Resistant Fecal Bacteria in Nepal Reflects Proximity to Kathmandu," Journal of Infectious Diseases, Vol. 184, No. 9, 2001, pp. 1163-1169. doi:10.1086/323647

[25] S. B. Levy, B. Marshall, S. Schluederberg, D. Rowse and J. Davis, "High Frequency of Antimicrobial Resistance in Human Fecal Flora," Antimicrobial Agents and Chemotherapy, Vol. 32, No. 12, 1988, pp. 1801-1805. doi:10.1128/AAC.32.12.1801 